\title{
The first published music from Antarctica? Captain Doorly's piano and its roots in older traditions of polar exploration and an imperial guilty conscience ${ }^{1}$
}

\author{
Jeff Brownrigg ${ }^{2}$
}

This chapter examines the roots of the first music known to have been composed in Antarctica or as a part of voyage to that region. It traces the souring of enthusiasm for polar exploration following the disastrous Franklin Expedition to discover the Northwest Passage in 1846, as more than a score of missions set out to discover what happened to Franklin and his men. Britons (and the world) followed the emerging story of Franklin's fate with growing incredulity and horror. The conclusions of searchers included well-supported charges of cannibalism and perhaps even murder, clear evidence of what appeared to be the utter degradation of British sailors as they faced annihilation.

Franklin has, of course, strong associations with Australia, and the ships he used on his last, fatal quest had been some of the first European vessels to venture into Antarctic waters in the first decades of the 19th century. Their loss generated a minute examination of sailors' lives and property. What had the desperate men selected to carry with them as they trudged away from their beset ship? What was life on board like? How were physical, psychological and spiritual needs met in resourcing journeys that might take years?

There is a curious relationship between the perception of the provision of music for Arctic and Antarctic expeditions. We know little of the musical lives of sailors on these ships, beyond the evidence of song, diary entries and the occasional painting. As it happened, music written on the support ship for Robert Scott's first Antarctic expedition was published in Melbourne. It was music that grew out of the need to re-establish a suitably wholesome, hearty and heroic spirit after the horror of Franklin's demise and what was seen at the time as nothing less than the decline of civilisation.

\footnotetext{
1 This paper was presented at the Antarctica and Music conference with a recital in which the Australian Rugby Choir gave a fine performance of these songs, reproducing the hearty spirit of the men who sang in the wardroom of the Morning in 1902.

2 Dr Jeff Brownrigg, Cultural Heritage Studies, Locked Bag 1, University of Canberra, ACT 2601.
} 
The British architects of polar exploration, principally Sir Clements Markham (Figure 1), imagined that the race to the South Pole might divert attention from the Arctic debacle and re-establish British pride and confidence in its Navy. A primary force who drove Scott's endeavour to be the first to reach the South Pole, Markham counselled that sledding dogs should not replace human effort, a costly and fatal error in what stands in relation to Arctic exploration as a counterbalancing Antarctic tragedy.

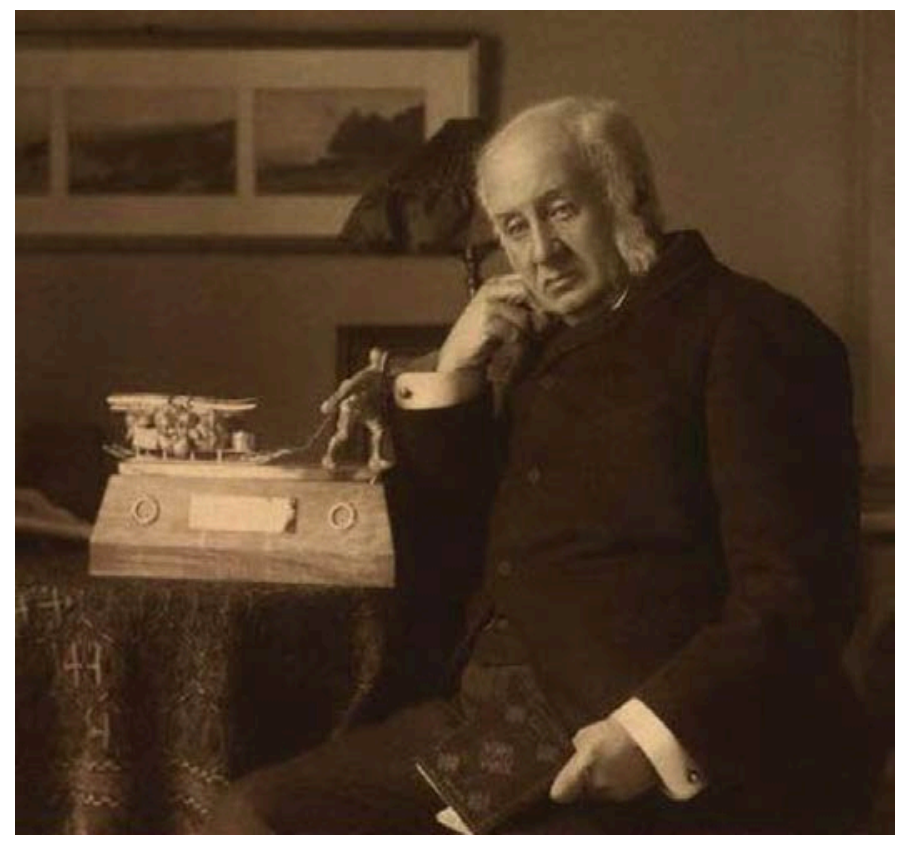

Figure 1. Sir Clements Markham, perhaps the most important link between Arctic and Antarctic polar exploration. As a young man he searched for Franklin. In later life he initiated and supported British polar expeditions in the first decade of the 20th century.

Source: Private collection.

Life-and-death decisions, ill-informed and brilliant judgements were part and parcel of the administration of dangerous adventures in hostile places, but some decisions were essentially benign. The campaign orchestrated by Markham saw the piano situated as a special implement of the polar explorer. Markham personally acquired an instrument for the supply ship Morning. Why was this?

There is nothing new in making a claim that the British Empire rose steadily in self-confidence and self-belief as the 19th century progressed. Just how 
these things manifested themselves in behaviour, bearing and action cannot be effectively scrutinised in a single strand of economic, or social, military or cultural history or any other sort of interrogation of the past.

Authority and purpose were reflected in a swaggering assertion of Britain's place, reflected as much in the music of composers such as Edward Elgar, or Parry, as anywhere else and fulsomely present in the singing of the Australian bass-baritone Peter Dawson, as 19th century mannerisms, ideas and enthusiasms carried over into the early 20th century. For 50 years after 1890, Empire ballads, like the grand orchestral statements of imperial pomp and circumstance, filled with energy and assertiveness, spilled from horns of innumerable gramophones and phonographs, providing a new twist upon the idea of the sun never setting; somewhere on earth people were listening to music that was quintessentially British. And yet, music, and sound more generally, remains at best an irregular component of the study of cultural heritage. Historians and others who write about the past are generally ill-prepared to discuss what is probably the most pervasive art form, after those things that are the component parts of speech as purveyors of memory in prose and verse narratives. Language - and English in particular - is steadily conquering the world since, at least, the accession of Queen Victoria.

Music, too, could colonise, in addition to all of those other things it did evoking and sustaining the past, identifying what Britishers had in common, speaking to shared core values and inculcating attitudes and values among peoples who were neither Anglo nor Celtic. After the 1890s, the great anthems and musical narratives of the Empire proudly suggesting an ascendant order were performed in most places where English was heard, underpinning a sense of belonging, a sense of the power of the whole imperial organism while almost inadvertently demonstrating the unifying capability of words and of melodies.

There were, of course, occasional dents in the otherwise pristine breastplate of ascendency. The Mardi, for example, inflicted one of these in the Sudan and many young Englishmen wearing scarlet jackets and bright brass buttons died against the austere, black background of the Khyber Pass, causing another blemish. An earlier incident — we might say 'defeat' - the loss of the Sir John Franklin's expedition to discover the Northwest Passage in late 1840s, was delivered by nature rather than a human foe and it shook Victorian Britain, sending a ripple of anxiety around the globe. But any shakiness in the steady, guiding hand of the Pax Britannica was temporary, though Britons would never quite forget the tragedy. Franklin, looking for a sea route from the Atlantic to the Pacific, ${ }^{3}$ had disappeared, leaving a scattering of traces that appalled readers

3 The idea had a long history. It was a notion dabbled in by explorers such as Giovanni Caboto (John Cabot) working under the patronage of Henry VII, Elizabethan adventurer Martin Frobisher, and James Cook who 
of the Times in the early 1850s when the first shocking stories of the expedition's fate found their way into the comfortable Victorian parlours. His ships were equipped with technologies as innovative and 'modern' as gizmos developed to support life during space travel.

At some time after the 1850s a song, sometimes said to be the work of Jane Franklin (Franklin's widow), touched a chord in the British heart and remains in popular music today. ${ }^{4}$

To Baffin's Bay where the whale-fishes blow,

The fate of Franklin no man may know.

Ten thousand pound would I freely give

To say on earth that my Franklin do live.

But Franklin remained lost, his fate buried not so deeply beneath the snow and ice of Baffin Bay. More than ten thousand pounds was expended on desperate, essentially fruitless rescue attempts in the decade following his disappearance. The Arctic offered up tantalising hints of a story and continues to do so. Missions seeking to discover what had happened to Franklin's ships Erebus and the Terror and the couple of hundred souls who sailed in them have continued to the present day. What the scattered clues suggested was a desperate battle for survival against the odds, and the abandonment of civilised values; the degradation of human beings who, under the most extreme stress and challenged by hostile elements that dictated their fate, abandoned long-held moral precepts. The very suggestion of cannibalism besmirched the English character.

Andrew Lambert, in a recent account of Franklin's life (and death), wrote in 2009:

[Franklin] did not live to witness the last days of his expedition, when the veneer of civilisation lifted to reveal primeval savagery, darkness and despair. ${ }^{5}$

All of Franklin's men died, many, perhaps most, having been reduced to eating their fellows in a desperate attempt to survive, butchering dead companions to obtain a portable food source which they carried until they too dropped. But an unspoken question haunted these revelations. Had British servicemen been driven to murder by desperate hunger? The very thought compounded the revulsion. 


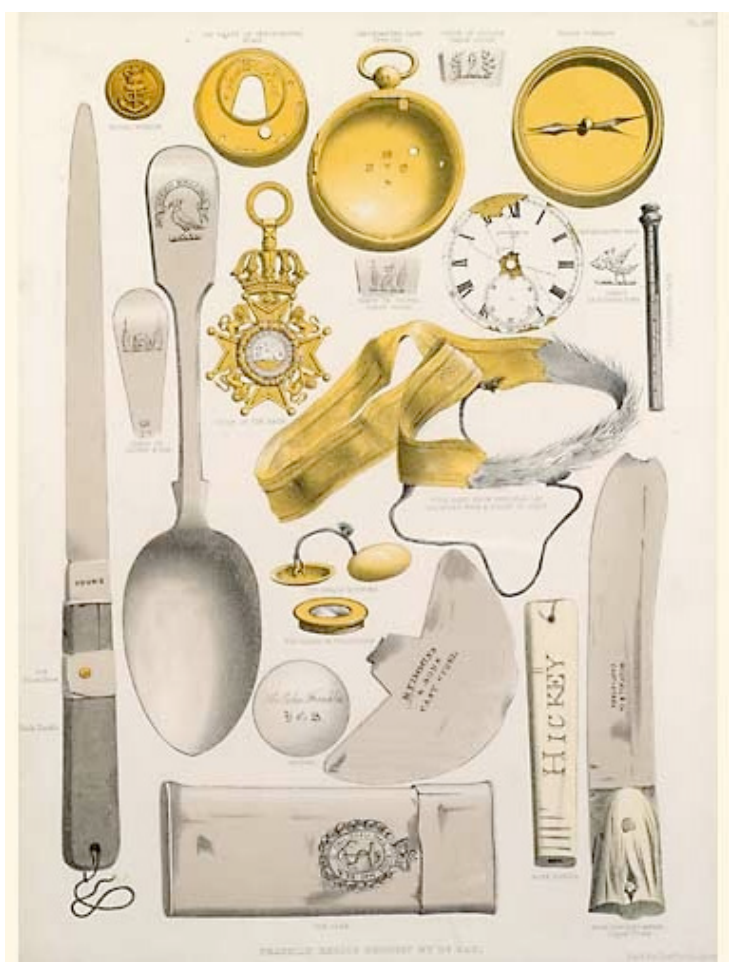

Figure 2. Relics of the Franklin Expedition collected by Dr John Rae in 1853-54 as published in 1855. Many of the items were identified as the property of particular crew members, including Franklin's medallion, clearly visible in the only surviving, somewhat ghostly, photograph of Sir John taken on the eve of his final voyage.

At first such stories were discounted; even Charles Dickens, a potent force at the cutting edge of popular culture, questioning the descent into unspeakable horror that ran counter to the accepted understanding of what it was to be civilised. Franklin's men, Dickens wrote, were:

The flower of the trained English navy ... it is the highest degree of improbability that such men would, or could, in any extremity of hunger, alleviate the pains of starvation by this horrible means. ${ }^{6}$

Finally, an incredulous Dickens blamed the Inuit from whom graphic accounts of the last days of Franklin's men had been collected. These accounts were progressively augmented as new expeditions brought back eyewitness accounts

6 Lambert (2009) Franklin: tragic hero of polar navigation pp. 250-2; Martin W Sanders (2006) Resolute. Sterling, New York, p. 140; Owen Beattie (1987) Frozen in time: the fate of the Franklin Expedition. Bloomsbury, London, p. 60. 
of the dreadful events of 1846-48. There were stories of the dismemberment of corpses, tales supported by a few human bones showing clear evidence of butchering.

In 1987 Owen Beattie exhumed the frozen bodies of three of Franklin's luckier men who had died from a combination of tuberculosis and lead poisoning early in the voyage (1846) and who were buried in frozen ground. Beattie determined that conditions dangerous to health were unwittingly exacerbated by new technology. Tuberculosis was made more virulent in the damp warm atmosphere of the claustrophobic spaces aboard Franklin's damp, centrally heated ships. Beattie concluded that canned provisions, first widely used during the Napoleonic wars, had leached lead from inefficient soldering into preserved food. ${ }^{7}$ Franklin and his men were, in effect, killed by their food and accommodation. This was supported by research in the late 20th century. Officers on better rations, and hence higher doses of lead, almost certainly suffered impaired reasoning. In 1987, filling out the background of his autopsies by mirroring something of the dismay felt in the 1850s, Beattie wrote:

Even today the stories are so abhorrent that they can hardly be believed. The Inuit reported finding boots filled with cooked human flesh, flesh that had been boiled. 'Some bones had been sawed with a saw; some skulls had holes in them,' Hall [writing after his 1869 search] wrote. Other bodies found nearby had been carefully stripped of flesh. ${ }^{8}$

Subconsciously, perhaps, Beattie nursed an idea that lead poisoning had caused behaviour that in different circumstances might have been kept in check. Polar exploration, however, was inherently dangerous, its extreme conditions capable of causing civilisation as it was understood to collapse. ${ }^{9}$ Starvation leading to cannibalism was, of course, not unknown in the 19th century. Théodore Géricault's painting 'Raft of the Medusa' (painted in 1818-19) illustrates an event in French naval history in which shipwrecked sailors adrift in the Atlantic were forced to eat each other. Understanding the risks involved in polar exploration might have led to adequate, meticulous preparation, but Fate could also deliver the unexpected, as it did in the American space program on 28 January 1986 or high in the Andes in 1973. ${ }^{10}$

7 Beattie (1987) Frozen in time, pp. 156-63.

8 Beattie (1987) Frozen in time, p. 60.

9 In the late 1820s Franklin had been involved in an expedition in the Arctic in which men had starved to death, and, it was said, had been reduced to cannibalism. Franklin became known as 'the man who ate his boots' but this might not have been the whole story. If cannibalism occurred, it remained a closely protected secret.

10 After an airplane crash in the high Andes a South American soccer team survived by eating flesh from those who died in the accident. The incident generated a book and film, both called Alive. 
As early as 1854 (in a letter to the Secretary of the Admiralty), Dr John Rae formally broke the news of 'a fate terrible as imagination can conceive' ${ }^{11}$ In 2009 historian Andrew Lambert concluded that lamentation for the loss of Franklin and his crew was transformed into deep repugnance. Such was the outcry at the thought that Englishmen, regardless of the duress they experienced, might eat each other, that the public needed a distraction. Polar exploration was instantly tainted and settled, for a time, on a pragmatic, discreet back-burner.

The saga of the Franklin rescue missions (there were 25 expensive major expeditions up to 1880) lingered after the 1850s as the chance of finding survivors - perhaps living with the Inuit - diminished, the vaguest hope dwindling in the face of accumulating evidence.

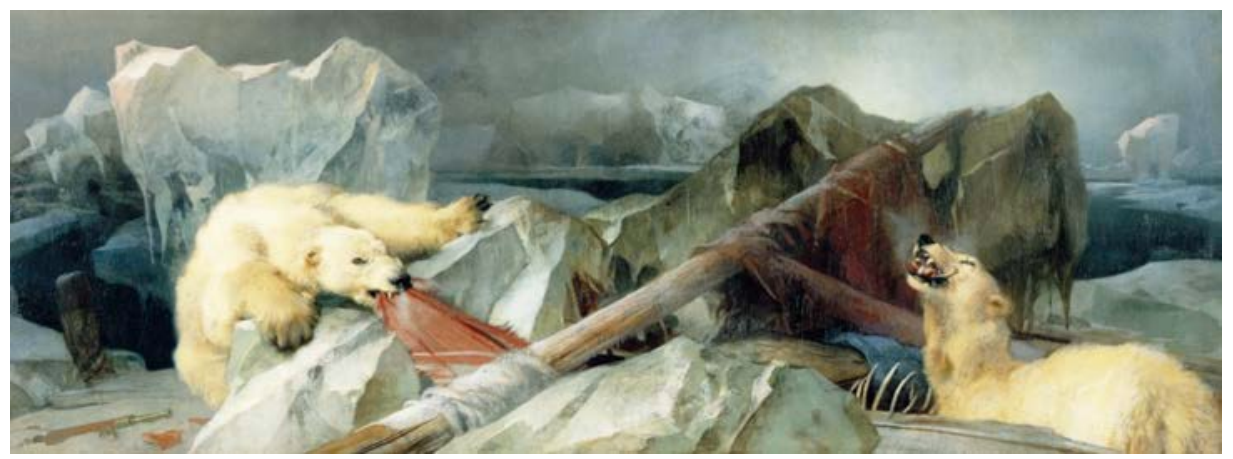

Figure 3. Painting by Sir Edwin Landseer, 'Man Proposes, God Disposes' (1864), often considered to have been influenced by the fate of the loss of Franklin's expedition to find the North West Passage.

But while desire for an accurate picture of what had happened remained after the passionate searches had all but concluded by the 1880s, the Franklin legend was transformed and sanitised in the 1890s by moving the focus of polar interest to the South Pole. Organisations such as the Royal Geographical Society, sponsoring research on what were perceived as the Earth's last frontiers, looked for a new spin that might encourage the necessary forgetfulness of what had been, something that invigorated enthusiasm for the heroic quest of figures who could be made as powerfully attractive to the public imagination as the courtly, chivalric characters of Tennyson's poems or those in the novels of Sir Walter Scott.

11 Letter dated 29 July 1854 from John Rae to the Secretary of the Admiralty. In McGoogan, Ken, ed. (2012) The Arctic journals of John Rae. Touchwood Editions, Canada, p. 240.

Dr John Rae had been second in command to John Richardson in a 1848 expedition to find Franklin. In 1853 he discovered a variety of relics and more importantly, testimony of the indigenous people of the region, often horrible and graphic in their detail. Rae was generally ridiculed in the UK. However, cannibalism and polar exploration remained linked into the 20th century when Mawson's survival seemed to some to have been effected by eating a comrade. 
Lambert argues that 'the Antarctic provided a perfect replacement to wipe the Arctic' and, presumably, behaviour Victorians most often attributed to 'savages', 'from the national memory'. ${ }^{12}$ Civilisation, in the words of Lord Tennyson (Poet Laureate for much of the time that the 'find-Franklin' expeditions were actively engaged in the search), would be best served and demonstrated beyond doubt by further excursions into the dangerous places; forays in the home of blizzard or the polar bear. The human spirit would prevail regardless of the infirmities of humanity or its previous misadventures. Tennyson, who was related to Franklin by marriage, had written in 1833 a poem that instantly inspired and endured even as details of the Arctic disaster were recovered and interpreted.

'Tis not too late to seek a newer world.

Push off, and sitting well in order smite

The sounding furrows; for my purpose holds

To sail beyond the sunset, and the baths

Of all the western stars, until I die.

It may be that the gulfs will wash us down:

It may be we shall touch the Happy Isles,

And see the great Achilles, whom we knew

Though much is taken, much abides; and though

We are not now that strength which in old days

Moved earth and heaven; that which we are, we are;

One equal temper of heroic hearts,

Made weak by time and fate, but strong in will

To strive, to seek, to find, and not to yield. ${ }^{13}$

Doubtless Tennyson's verse was included among the 1,700 volumes that were packed into the ward room and other cabins of the Erebus in 1845. Tennyson was standard fare for the middle and late Victorians. Franklin's men, had they the time to read Tennyson on their final voyage, would have recognised themselves and the adventurous, inquisitive spirit the poet describes.

Tennyson's classical allusions were deeply resonant throughout the Englishspeaking world at the time, but the principal figure in packaging Franklin's story as a heroic adventure, albeit in the well-worn Tennysonian chivalric tradition, was Sir Clements Markham.

12 Lambert (2009) Franklin: tragic hero of polar navigation, p. 350.

13 These are the final lines of Alfred, Lord Tennyson's much anthologised poem 'Ulysses' (source http:// www. bartleby.com/42/635.html, accessed 26 August 2014). Written in 1833, they were first published in his second volume of verse, Poems, in 1842. 


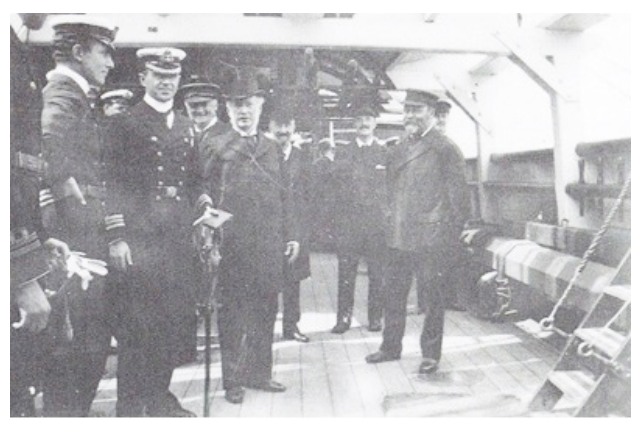

Figure 4. Sir Clements Markham (front centre, with top hat) at the departure of the Robert Falcon Scott's ship Discovery in 1901. Scott, in his naval uniform is first of Markham's right. Next right is Lieutenant Engineer Skelton, the subject of vaudeville song at the Royal Terror Theatre, McMurdo Sound, 1902.

Markham had been there as the saga of the search for Franklin began, serving as midshipman on the HMS Assistance during the Royal Navy's major search in 1850-51. Later he was Secretary to the Royal Geographical Society from 1863 to 1888 , becoming its President from 1889 to 1901 . So 50 years after searching for Franklin, he played a crucial supportive role in the design and realisation of Robert Scott's first Antarctic expedition of 1901-1904 (Figure 4). His views on all subjects were accepted as informed by long experience even when his judgement was flawed or simply wrong. Dog sleds, for example, might have given Scott extra impulsion and he might have beaten Amundsen to the Pole. This is speculation, but discussions of Scott's failure often turn to his adopting the old ways; stout-hearted men hauling all that was needed for survival, much as the remnants of Franklin's party had manhauled supplies and the miscellaneous matter that littered the route of their doomed trek. Markham was possessed by the idea that Franklin's tragedy should not be repeated in the South. He turned his mind to the most minute details and inflicted them, brooking no opposition.

Searching for the model of an ideal polar explorer, Markham had written, in 1875:

The most valuable qualifications for Arctic service are aptitude for taking part in those winter amusements which give life to the expedition during the months of forced inaction [etc.]. ${ }^{14}$

Markham was 15 on 19 May 1845 when Franklin's ships had sailed from the Thames, so 30 years of observation must have nurtured in him the opinion that the long incarceration of 'wintering' near the poles should be accommodated with supplies that encouraged appropriate pastimes. The alleviation of

14 Lambert (2009) Franklin: tragic hero of polar navigation, p. 318. 
boredom, banishment of anxiety and homesickness, and personal growth and development might all be addressed with appropriate provisioning. Markham's pronouncements, with Franklin's expedition clearly in his thoughts, ensured that a variety of musical instruments were included in the fitting out of Scott's ship Discovery and that of the supply vessel Morning. Franklin, too, had carried musical instruments; two hand-operated reed instruments (hand organs) which utilised folded, punched cardboard, not unlike the programs of holes on a paper roll provided 50 years later for Scott's pianola. (There was nothing particularly innovative or especially new about providing for the mental health of sailors who might endure months of relative isolation on long voyages even if they were not ice-bound. ${ }^{15}$ ) Music-making machines (hand organs and pianolas) allowed the musically unskilled to produce reasonable quality performances simply for listening or for accompanying singers. The Erebus and the Terror had 'encoded' performances of familiar tunes and also a selection of more than a dozen hymns, so body and soul were clearly catered for. Scott's expedition also had a harmonium (a reed organ, of the sort used in small churches).

Markham personally selected a piano for the Morning and it arrived just in time to be loaded.

Scott's party had been in Antarctica for a year (1901-02) when the first relief ship was despatched, and in that time a powerful interest in 'theatricals' had evolved in the group. Markham's philosophy concerning mental health was made tangible and Scott's men demonstrated their 'aptitude for Arctic service', albeit in the Antarctic.

During that first 12 months in Antarctica, members of Scott's team commandeered a local hut and established it as the 'Royal Terror Theatre', putting together plays, reviews and concerts, often attaching new words to well-known melodies. In one of these, a popular song by Marie Lloyd (a towering presence in English music hall and review) was transformed into a parody sharply focused on the Discovery's first engineer, Reginald Skelton. The original was performed by Marie Lloyd - who had performed in Melbourne in May 1901 at the opening of the newly built Opera House at the same time as Markham issued final 'Instructions to the Commander of the Expedition' party. (Discovery sailed from the UK on 6 August.) An audience favourite from its first presentation in 1893, 'Oh Mister Porter' included the following catchy chorus:

Oh Mr Porter, what shall I do?

I want to go to Birmingham

And they've taken me on to Crewe

Take me back to London quickly as you can.

15 Cook was a masterly psychologist, and numerous expeditions of his time and later set up amateur music and theatricals to salve the tedium of containment on board ship. 
Oh Mr Porter what a silly girl I am! ${ }^{16}$

In the hands of Stoker Page - who wrote new words for the popular tune the song gently poked fun at Skelton, recognisably an example of the lowly having a good-natured shot at their betters and certainly evidence of the sort of esprit de corps that Markham encouraged. (Skelton had overseen the building of Discovery in Dundee and had a 'parental' interest in the ship.) Scott's men also poked fun at the tedium of their routine duties.

Oh Mr Skelton, what shall I do?

You've sent me to the boiler

When I'd rather be in the flue.

Send me in the bilges as quickly as you can,

Oh Mr Skelton, you're a very nice young man. ${ }^{17}$

The Antarctic audience found the imprecations of the humble stoker amusing, but the Royal Terror Theatre endured only a single season before it was required for storing sledges. Its reassignment saw the enthusiasm for amateur theatre dramatically wane.

Providing the words was one thing, writing words and tunes, another and it was there that the crew of the Morning extended what Scott's colleagues had started.

On 25 June 1902 the Morning left East India Dock in London to find Scott and to supply the British Antarctic Expedition, but just before the Morning sailed, a piano was delivered to the ship, a farewell gift from Sir Clements Markham following a suggestion from Second Executive Officer Edward 'Teddy' Evans, later Admiral Sir ERGR Evans KCB, DSO (and later still, Lord Mountevans).

If any part of the Morning's remarkable history is recalled today, it is the surgery performed (at sea) on Markham's piano that has lingered in memory (Figure 5). Doorly's writings concerning the voyage (especially the books and pamphlet published in 1916, 1937 and $1943^{18}$ ) included a line drawing of the operation necessary to get the instrument below deck.

\footnotetext{
16 Marie Lloyd (1977 ) Song book. EMI 'The Music Makers' Series. EMI Music Publishing Ltd, London, p. 62 .

17 Mike Pearson (2004) 'No joke in petticoats: British polar expeditions and their theatrical presentations'. $T D R, 48(1)$ Spring: pp.44-59. The words of the song/parody are presented as a continuous line, p. 49.

18 The original edition (there has only been one) of In the Wake (ca.1937) is undated, but the title page includes a list of Doorly's publications including The Songs of the 'Morning' which was certainly published in 1943 in an edition that is dated (Gerald Doorly (1943) The Songs of the 'Morning', Bread and Cheese Club, Melbourne). The copy used in research for the present article has a birthday inscription dated 16 July 44 . This means either that the original edition was published after the date accepted in, for example, the entry in the Australian Dictionary of Biography, or that changes were made to the title page in a new edition in or about 1943. No copy of Handmaiden of the Navy, Doorly's history of the Merchant Marine, has been sighted.
} 


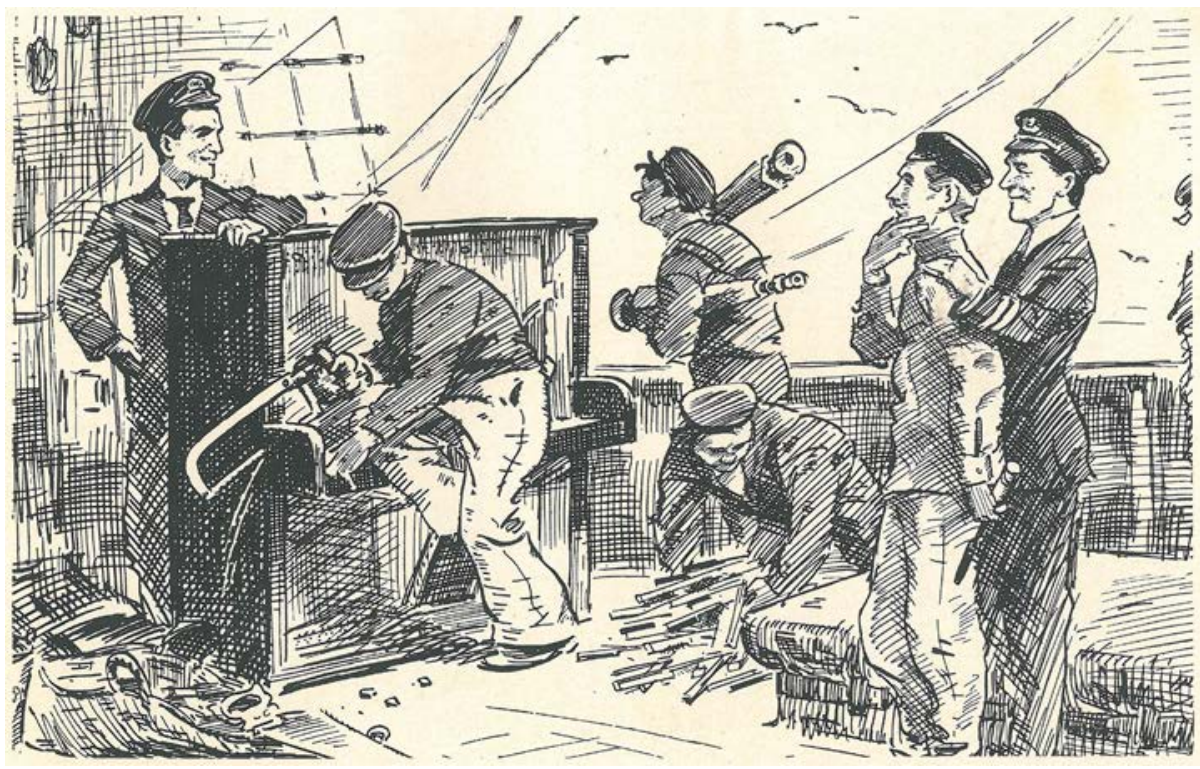

Figure 5. 'Dissecting the piano.' Markham's last-minute gift was too large to be stowed below decks without considerable modification.

Source: Sketch from The Songs of the 'Morning' (1943).

In essence, the keys were removed, the legs supporting the keyboard also detached together with the protruding keyboard structure - the shelf that cradled the keys - was sawn off with a meat saw borrowed from the kitchen. Once below deck and safely in the tiny ward room, the instrument was reassembled and put to use.

Removing the piano to the ward room was effected in the first days of the voyage. It took 135 days for the Morning to steam and sail from the UK to New Zealand, and after three weeks in the 'Land of the Long White Cloud', several more weeks seeking Discovery. Time presented ample opportunity to use the instrument. Ships were survival capsules. This was true for Franklin as it was for Scott. Ocean voyages were perilous and an ice-bound ship a refuge at the hostile poles. In 1911 Shackleton's Endurance was finally crushed, as both the Erebus and Terror appear to have been in about 1848, but for a time each afforded shelter to stranded crew. Regardless of circumstances, voyaging or wintering in the ice, as long as the integrity of the fabric of the ship was not compromised, a piano was a useful piece of equipment.

Travelling or stationary, it was James Gerald Stokely Doorly who played the doctored piano more than his shipmates. Born in Port au Spain on 4 June 1880, Doorly's father was a clergyman who later became Archdeacon of Trinidad, 
where James Gerald went to school. Doorly was not, however, a highly trained musician. ${ }^{19}$ His pianism was learned incidentally and he probably played by ear. He trained as a cadet in the merchant marine at Thames Nautical College, graduating as a gold medallist in 1897, learning seamanship and navigation as he was fitted out for command. During the Boer War he worked on troop and hospital ships, but in 1902 he was signed up as third officer on the steam yacht Morning, which was to resupply the National Antarctic Expedition already testing itself at McMurdo Sound on the Ross Sea.

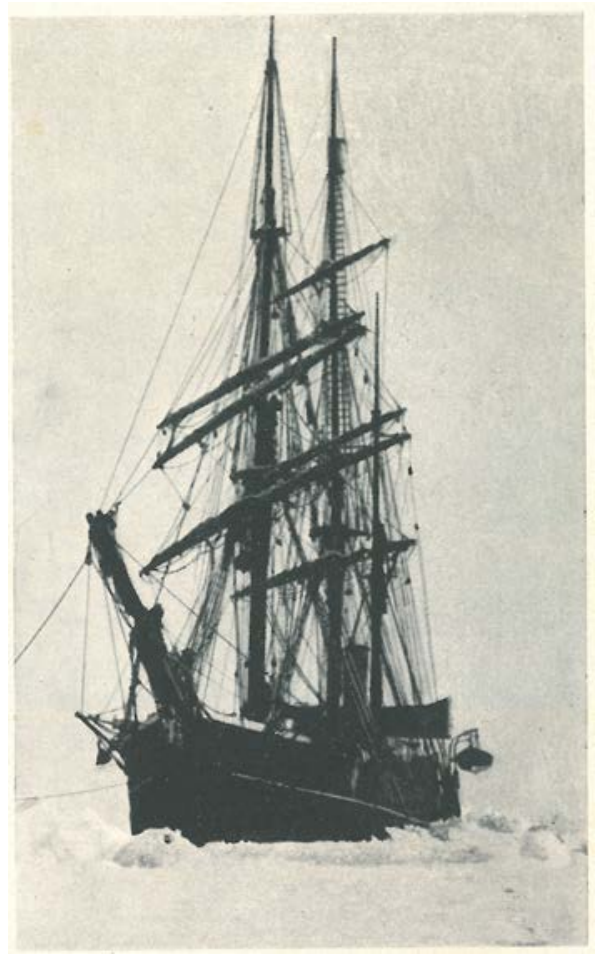

\section{Figure 6. The Morning trapped in ice. The image suggests the look of a photograph by Frank Hurley, who provided an image as the frontispiece in the same volume.}

Source: From In the Wake, Gerald Doorly's reminiscences published by Robertson and Mullens Ltd, Melbourne.

19 It is not clear for example, if the 1916 version of the music for 'Southward' is in Doorly's hand. The 1943 version was written by a more experienced copyist but reproduces exactly the same notes. The formation of notes and clefs is more sophisticated. If Edith Harrhy assisted Doorly in 1943 then there is no evidence of her having made any alteration to the original 1916 published version of 'Southward'. RH Croll, in his introduction to The Songs of the 'Morning' (p. 5), wrote that 'Miss Edith Harrhy, the well-known Australian composer has most admirably scored the full series, bestowing on it that order which was necessary to complete the work And make it an harmonious whole'. Perhaps this means that the songs published in 1943 are Edith Harrhy's transcriptions of published and manuscript pieces composed by Doorly. If so, Harrhy seems to have practised minimal intervention. 
By 1904 Doorly had gained his master's certificate, after which he mainly worked for the Union Steamship Company where his most notable accomplishment might have been his 1908 marriage to the owner-director's daughter. In 1917 he survived being torpedoed in the English Channel and in June 1925 he left the Union Steam Ship Company in New Zealand, taking up a position in the Port Phillip Sea Pilot's Service. Retiring from this job 20 years later, he lived in Melbourne until the early 1950s when he returned to New Zealand, dying in Wellington in 1956.

Although a couple of substantial prose works and occasional articles in newspaper and periodicals are his principal claim to fame, the seven songs of The Songs of the 'Morning', published in 1943 though written 41 years earlier, are his most important legacy (Figure 7). His recollections, setting out his various adventures with hearty good humour, are not, I think, as significant as his songs. The songs were, in Doorly's words, 'written and composed in the Antarctic' and like his claim that they had 'never hitherto been published', this was more or less true. From Doorly's biographical writing it is clear that they were written at different times during the long, often tedious voyage of the Morning between 1902 and 1904.

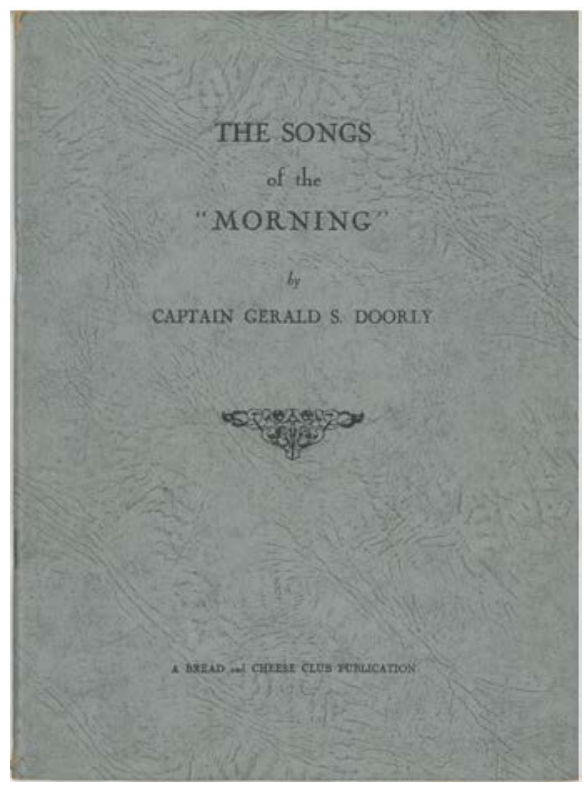

Figure 7. Cover of The Songs of the 'Morning'. This was probably the first published music written as the direct result of Antarctic polar exploration, and during it. Others as early as Cook's voyages might have played the fiddle and flute or sung, but there is no evidence of composition reflecting the experience of these activities in Antarctic waters. 
As the Morning steamed and sailed south in 1902, Chief Engineer JD Morrison provided words for 'Southward' (1), which Doorly set to an original melody. In his memoirs, Doorly explains that although the tune sounds a little like the opening chorus from Gilbert and Sullivan's The Gondoliers, he composed the song before he knew the operetta. ${ }^{20}$ 'Southward' was an instant success and initiated a fruitful partnership that lasted as long as the voyage. Others of the Morning's crew put pen to paper, producing rollicking good-humoured verse. Some of this has survived. The work of Chief Officer England ('You May Talk About Your Engines' and 'Song of the Stores'), Lieutenant GFA Mulock (and others) seem to have been produced for recitation rather than setting to music. ${ }^{21}$

Doorly and Morrison pooled their talents again for a song ['Drink to] The Northland' (2) for New Years Day or Christmas (or, indeed, any occasion requiring a toast). Both of these songs ( 1 and 2 ) appear to have been written on the outward voyage.

A third song, 'Birrd, Birrdie' with its rolled Scots 'r's, was written for the birthday of the ship's Scottish doctor, GA Davidson, whose job it was to capture and preserve creatures encountered during the voyage. ${ }^{22}$

The song carries Gerald Doorly's name as composer as well as the intelligence that this is a parody of an 'Old Irish Air'. Doubtless sending up the Scots with an Irish tune added relish to the humour, though the supposed 'Irish Air' is almost certainly Doorly's work.

'The Ice King' (4) was written as Morning searched the Antarctic coast looking for Discovery, eventually finding Scott's ship in McMurdo Sound (Figure 8). This is the finest song of the group, aspiring to catch a sense of gravity and awe associated with the Morning's departure. The ship, anchored off the edge of the ice that still trapped Discovery, watched the men from that ship wave them off. This song's words catch something of the inflection of the Empire ballad:

Bearing the flag of England

Far oe'r the frozen sea;

Their watchword and their haven

'Discovery' still shall be.

Watching the stars in their courses

Watching the needles swing

Doing their duty - not counting the cost,

20 Songs are listed here and numbered (in brackets) in their order in The Songs of the 'Morning' (1943).

21 See the liner notes for The Songs of the 'Morning': a Musical Sketch (CD, Reardon Press, ISMN: M90020680-0, ISBN-1-873877-52-8) 2002. England's poems are on p. 9 and p. 15 and Mulock's on p. 16.

22 No photograph of taxidermy being performed on the Morning seems to have survived. There is a photograph of Dr Wilson on the Discovery doing what is described in Doorly's song in Ann Savours (2001) The Voyages of the Discovery. Chatham Publishing, London. 
Till the 'Morning' comes with the Spring.

Refrain:

Far away in that cold white land,

In the home of the Great Ice King!

Braving his fury, daring his wrath,

When honour and glory are showing the path;

God will keep them from harm and scathe

Till the 'Morning' comes with the Spring.
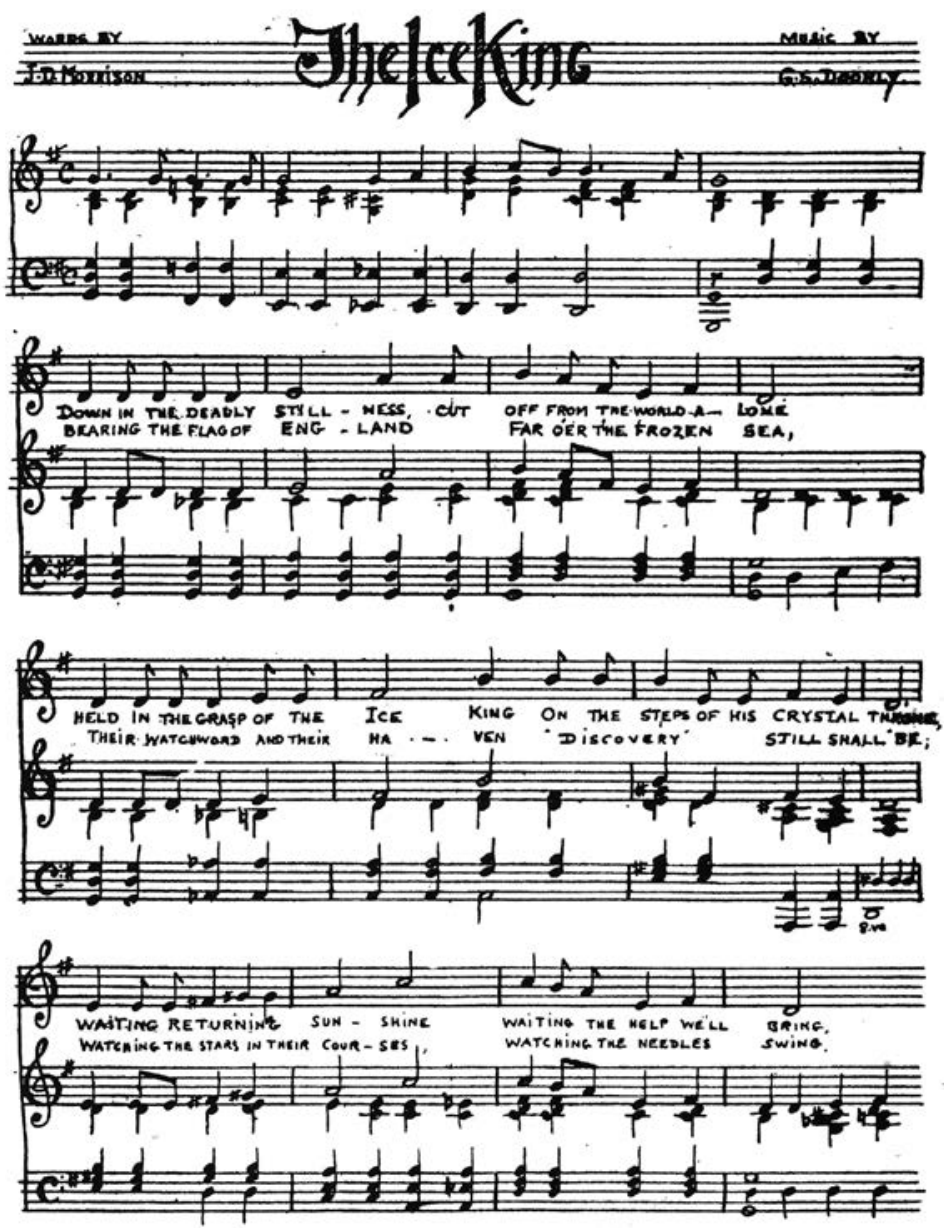

Figure 8. First page of 'The Ice King' from The Voyages of the 'Morning', 1916. 'The Ice King' is, perhaps, the most dramatic and evocative of the seven songs published by the Bread and Cheese Club, Melbourne, in 1943. Doorly wrote other songs but their current whereabouts is not know, if, of course, they have survived. 
As far as it is possible to tell, Markham did not hear or read these songs, but there can be no doubt that the old spirit was manifest in Doorly and Morrison's works. It seems likely that Doorly's selection of 'The Ice King' and 'Southward', both of which resulted from his collaboration with Morrison, indicates a special affection for these pieces.

As it happened the supply visit was unexpectedly short due to the weather. The exhilaration of having discovered Scott, feelings shared by supplier and supplied, was suddenly overtaken by pragmatism. Fearing that the ice would re-form, trapping the Morning, Scott ordered the ship back to New Zealand. A reluctant Ernest Shackleton was a passenger, having suffered the 'ravages of scurvy when returning with Scott and Dr Wilson from a 92-day's pioneering sledge journey towards the pole'. ${ }^{23}$ So too were nine other members of Discovery's crew when the Morning departed on 2 March 2003. ${ }^{24}$ Shackleton and Doorly wrote the words for 'Scotland Forever' (5) jointly sending up Morrison and Dr Davidson, members of the Morning's crew, both of them Scots.

It is difficult to place the last of the songs published in The Songs of the 'Morning', 'Yuss!' (6) but it seems probable that it was written when the New Zealand accent was a recent, vivid memory. Essentially, Doorly saw it as a sea song 'with a fine rollicking chorus'. Once again the stalwart lyricist JD Morrison provided the words.

'The Maid's Lament' (7) followed a visit to Christchurch; Doorly suggests that this was on the outward journey to Antarctica in 1902.

While the seven published songs are not strictly a song cycle — and there are other songs in manuscript that were not included in the 1943 publication they do document different parts of the experience of the Morning's first relief voyage. In contrast, a second relief voyage in 1903 appears to have been less productive of songs. The order in which they were published is not, I think, the order in which Doorly imagined them being sung, his own notes suggesting that 'The Maid's Lament' should be sung third and 'Yuss!' sixth. In a sound recording of a musical sketch entitled The Songs of the 'Morning', an eighth song by Doorly, 'Eight Bells' is also performed. ${ }^{25}$

The Songs of the 'Morning', published by the Bread and Cheese Club in Melbourne, is almost certainly the first music written on a voyage associated with and in Antarctica to be professionally printed and distributed as a cohesive collection. The words and music of 'Southward' and 'The Ice King' were first printed in

23 Doorly (1943) The Songs of the 'Morning', p. 15.

24 Doorly (1943) The Songs of the 'Morning', p. 15.

25 It is not clear from the liner notes booklet whose arrangement this is, though the whole is credited to Doorly. It seems likely that Doorly played 'by ear'. See The Songs of the 'Morning': a musical sketch (2004). Reardon Publishing, England, recorded in Wellington NZ in February 2002. 
Doorly's The Voyages of the 'Morning' in 1916 as illustrations of activities on board that vessel in $1902 .{ }^{26}$ They are, of course, in a tradition. James Cook, whose crew almost certainly included sailors with practical musical abilities, captained the first European ship known to have crossed the South Polar circle in 1773. It is not clear if their music included original compositions. Others followed, first in frail sailing ships and later in more robust, manoeuvrable steamers but none, as far as I can tell, generated music which was original and published. Scott's thespian troupe in the Royal Terror Theatre certainly found new words for familiar tunes and some of these can be assembled from their scattered parts; a tune from a musical, scripted material recorded in a diary or in the purpose-built periodical the South Polar Times, this last an amateur handmade newspaper.

The publication of The Songs of the 'Morning' was the result of several pieces of good fortune. First was the philosophical position of Sir Clements Markham, as well as Markham's authority as one who had experience of polar exploration. As president and long-serving secretary of the Royal Geographical Society, he was also able to command the attention of powerful and influential allies who might support polar enterprises. Without Markham the resurgence of polar exploration in last years of the 19th century might not have happened. He was able to put into action his longstanding sense of the qualities desirable in the ideal polar explorer. He was often criticised for his dictatorial manner and his inclination to stand in the way of anybody, however successful they might have been in their polar exploits. He was not alone in this but Morning's crew seem to have treated him with affection. JD Morrison's poem called 'Klementz, the President Boss of the Gheographez' might have been a song-text but the music for the piece is not known at present. It is notable for the last line in the citation below.

Thus spake Zirklementz, Boss of Gheographers

Boss of the people who knew about everything,

'Find me a man who is skilled in the depze!

Who noz about izbergs and blizzardz and suchlike,

And instruct him to build uz a ship at great expense

Phitted with the meanz of taking Pickturz

And making of music ...'

Ernest Shackleton, at one time Markham's protégé, was obliged to follow his mentor in some respects. Potential participants in a new expedition in 1909

26 A later edition of The Voyages of the 'Morning' published by Bluntingham Books, Norfolk, in 1995 includes what appear to be facsimile copies of 'Southward' and 'The Ice King' taken from The Songs of the 'Morning' (1943) in Edith Harrhy's arrangements. They are in the same musical hand but are not identical. See for example, the lettering of the titles of both songs. 
were interviewed by Shackleton and were often asked if they were singers. Like Markham (and reworking an old proverb), Shackleton seems to have believed that those who sing together, cling together.

If Markham's primary gift of making the 1901-04 British National Antarctic Expedition happen was his major contribution, his briefing of Scott and others was equally significant. Recollections of the British Navy entertaining itself in the early 19th century probably informed his thinking.

And then there was that essential tool of polar exploration, the piano.

Doorly made the most of it and, with Morrison, gathered those around him into a close, productive relationship following Markham's directive. The songs he wrote were modest. As Morrison, his most productive and inspired lyricist, presented the would-be composer with words for 'The Northland', he exclaimed (in Doorly's transcription of Scots), with an urgency driven by his passion as well as his local success:

Doorly, Doorly, quickly luke [look] at these words - now here's a song for ye - if ye can get a tune for that now our name's made! ${ }^{27}$

Doorly notes, sardonically, in his 1916 memoir that Morrison was 'a bit previous'. From the beginning musically critical people might have agreed. But this is a case where context endows the products of a particular occasion with peculiar significance; a splinter of the heritage of Antarctic experience in the heroic age.

Fate, fickle as she often is, might have seen the songs consigned to even more obscurity than they suffer at present. The two pieces included in The Voyages of the 'Morning' would have remained accessible there as book publishing lurched into the digital age. But it was Doorly's move to Melbourne that made the difference. He became a more regular journalist, writing for the Bulletin and the Melbourne Age and, from 1938 to 1956, he was a member of the Bread and Cheese Club. The club was one of the bastions of middle-class bohemianism. Like the Melbourne Democratic Club at the end of the 19th century, under whose auspices the singer-songwriter Billy Williams got his start, Bread and Cheese encouraged and published its own. RH Croll, a now forgotten Australian literary celebrity of the 1930s and 1940s who wrote the introduction, speaks of The Songs of the 'Morning' standing for 'romance and high adventure'. Croll also notes that the musical arrangements in the publication were the work of the then well known Australian composer Edith Harrhy, but the central theme in all that he has to say concerns 'the comradeship and good humour' which he notes are manifestly there in Doorly's songs. 
There is no sterner test of the ability of men to live together harmoniously than would be imposed by months of confinement in such a small vessel ... They must be self-contained in all that life could mean for them; above all they must create their own entertainment - that spiritual vitamin so essential to mental health ...

It seems fitting that it [The Songs of the 'Morning'] should be presented to the public by a Club whose motto is Mateship. ${ }^{28}$

Only a few physical remnants of Franklin's last, fatal voyage have ever been found. The expedition lives in imaginations fed by legend, surmise, as well as a few bones and trinkets that seem to tell a tale. In some accounts the explorer was buried in the ice not far from his beset ship. That seems strange unless his crew imagined that his remains might be recovered once his ships were free of the ice that gripped them. Others have him transported to King William Island or even the Canadian mainland to be interred in earth. A single tangible item, a relic of his knighthood, found its way back to his wife.

In Westminster Abbey a small memorial marking his achievements includes an epigraph by Tennyson who, through the voice of Ulysses, had urged his fellows to fearlessly seek the unknown, to face adversity and danger with a clear eye and a concept of the 'rightness' of the explorer/adventurer's quest.

Not here; the white North has thy bones, and thou

Heroic sailor soul

Art passing thy happier voyage now

Towards no Earthly Pole.

It was a spirit evident in the tragedy of Robert Scott at the other Pole. By comparison, Scott left much more of himself, seemingly aware of the likelihood that his name would endure. Gerald Doorly has his name forever attached to a minor peak near Mt Erebus and its smaller neighbour Mt Terror. The major peaks had been named by Captain Crozier who later commanded the Erebus on its final journey. As a member of the Ross party when the Erebus and Terror visited the Antarctic in 1841, Crozier had captained the Terror.

The Empire, in which Scott became an indelible hero, worshipped his striving until the 1950s when wide-eyed Australian schoolchildren marvelled at his leadership and the selflessness of Captain Oates. The heroic age continued, its sights upon the 'first to get there' philosophy that saw dozens die in the frozen landscape of another hostile frontier, the higher slopes of Mt Everest.

In the 1950s, Australian schoolchildren learned that such unyielding striving was desirable and important to the prestige of the Empire. It wasn't long before those children looked to the eastern sky for Sputnik as the 'space race' began. 
Who would put the first man on the moon? New frontiers presented different dangers, but little changes. 'Though much is taken, much abides', Tennyson had written in 1833. There is no evidence that astronauts have been driven to eat each other. How much smaller are a few occasional songs in the scheme of things when juxtaposed with man and nature in conflict?

Doorly survived to see his modest works in print, playing a bit-part in the first heroical and then tragic expeditions of Robert Scott. Doorly's contributions were of a different order. Legends of violent death in uncontrollable circumstances seem inevitably to be more enduring than tunes and words that have grown out of fairly ordinary experience. Some remembered Franklin with a song which has endured, but the circumstances that put Captain Doorly's piano into the ward room of the Morning have their roots in one of the foremost tragedies of the Victorian age, which saw the very foundations of civilisation shaken. His songs remain a tangible link to the endeavours of exceptional, ordinary men whose lives intersected those judged in their time to be heroic.

\section{Coda}

One of the few upsides to the progress of global warming is that it is likely to stimulate new expeditions in search of the truth about Franklin's last expedition. Polar ice is melting and Canadian maritime archaeologists have suggested that a deep-sea search might discover the remains of the Erebus and the Terror. What clues have survived the destruction of the ships and their long immersion is a matter for conjecture, but a new post-greenhouse expedition is unlikely to carry a piano or result in the composition of songs. Another dimension of modernity is the shortage of time for the leisure to compose and perform, new technologies having made travel quicker and ready-made digitally encoded and satellite-delivered entertainment easily accessible. Deep-sea diving equipment might, following sonar mapping of the ocean floor, disclose the wrecks of Erebus and Terror. Discussion as to whether the site might be combed through archaeologically, or is seen as a place where human remains are likely to be found and left untouched, need only follow a positive identification. Just what might result from risk-taking in Arctic waters is unclear but these explorers of a new frontier will be operating in a venerable tradition. 
This text is taken from Antarctica: Music, sounds and cultural connections, edited by Bernadette Hince, Rupert Summerson and Arnan Wiesel, published 2015 by ANU Press, The Australian National University, Canberra, Australia. 